

\title{
The Effectiveness of Ethanol Extract in Muli Banana Peels (Musa Acuminata) to Heal Cut Wounds in Mice (Mus Musculus L.)
}

\author{
Eriola Maulidya $^{1 *}$, M. Kanedi' ${ }^{2}$, Yulianty ${ }^{3}$, Eti Ernawiati ${ }^{4}$ \\ 1, 2, 3, 4 Biologi FMIPA, Universitas Lampung, Indonesia
}

\begin{tabular}{l}
\hline ARTICLE INFO \\
\hline Article History \\
Received : April 17th, 2020 \\
Accepted : May 19th, 2020 \\
Published : June 29th, 2020 \\
Keywords: \\
Bananas; \\
Wound healing; \\
Mice \\
*Correspondence Address: \\
eriolamaulidya97@gmail.com
\end{tabular}

\begin{abstract}
Muli banana peels contain flavonoids, saponins, and tannins that foster the process of wound healing. The purpose of this study was to determine the effect of ethanol extract in muli banana peels (Musa acuminata) on cut wounds healing process in mice (Mus musculus). The study design was the completely randomized design by using 24 male mice which were divided into 6 groups, namely (K+, K-, P1, P2, P3, and P4). Each treatment consisted of 4 mice. All groups of mice were treated with a $1 \mathrm{~cm}$ cut wound on the back. The $\mathrm{K}+$ group as the positive control group were applied with povidone-iodine, the K- group as the negative control group were applied with distilled water, the P1 group was applied with a concentration of $10 \%$ extract, the P2 group with $20 \%$ extract, the P3 group with $30 \%$ extract, and the P4 group with $40 \%$ extract for 14 days. On the 15th day, histological slides were made by taking 1 sample from each group. The results showed that the ethanol extract of muli banana peels played a role in the cut wound healing process.
\end{abstract}

Uji Efektivitas Ekstrak Etanol Kulit Buah Pisang Muli (Musa Acuminata) Terhadap Penyembuhan Luka Sayat Pada Mencit (Mus Musculus L.)

\begin{abstract}
Abstrak: Kulit buah pisang muli mengandung senyawa flavonoid, saponin dan tanin yang memiliki peranan dalam proses penyembuhan luka. Tujuan dari penelitian ini adalah untuk mengetahui pengaruh pemberian ekstrak etanol kulit buah pisang muli (Musa acuminata) terhadap proses penyembuhan luka sayat pada mencit (Mus musculus). Rancangan penelitian yang digunakan adalah rancangan acak lengkap, menggunakan 24 ekor mencit jantan yang dibagi menjadi 6 kelompok yaitu $(\mathrm{K}+, \mathrm{K}$-, P1, P2, P3, P4) dengan masing- masing perlakuan terdiri dari 4 mencit. Semua kelompok mencit diberi perlakuan luka pada punggung sepanjang $1 \mathrm{~cm}$. Kelompok $\mathrm{K}+$ sebagai kontrol positif dioleskan povidone iodine, kelompok $K$ - sebagai kontrol negatif dioleskan aquades, kelompok P1 dioleskan ekstrak konsentrasi 10\%, kelompok P2 dioleskan ekstrak konsentrasi 20\%, kelompok P3 dioleskan ekstrak konsentrasi 30\%, dan kelompok P4 dioleskan ekstrak konsentrasi 40\% selama 14 hari. Pembuatan preparat histologi dilakukan pada hari ke 15 dengan mengambil 1 sampel
\end{abstract}


dari tiap kelompok. Hasil penelitian menunjukan bahwa ekstrak etanol kulit buah pisang muli berperan dalam proses penyembuhan luka sayat yang dilihat dari gambaran histologi lebih baik dibandingkan kelompok kontrol.

\section{INTRODUCTION}

The skin is the largest organ because it encloses the entire outer surface of the body (Muthia, Titin, \& Neneng, 2019). The thicker skin is located on the back, shoulders, soles of the feet, palms, and buttocks (Putrinda, Budi, \& Rudy, 2014). The skin protects parts of the body from physical and mechanical disturbances that occurred outside of the body (Hadi, 2006; Nuzantry \& Widayati, 2015). The disturbances from outside of the body are traction, harmful chemicals, pressure, friction, fungal infections, radiation, and UV exposure (Maulidya, 2019). Body injuries can be caused by explosions, electric shock, animal bites, changes in temperature, chemicals, and trauma by sharp or blunt objects (Darwis, Hardiningsih, \& Nurlidar, 2013; Ningsih \& Paturusi, 2015).

One of the wound healing processes is the vascular response where the blood vessels narrow to inhibit bleeding (Oktaria \& Fazriesa, 2017). Povidone-iodine as the wound medicine is often used to accelerate the rate of the wound healing process and to reduce the risk of minor infections (Yufdel, Nasution, \& Harahap, 2015; Zuhan, Rahman, \& Januarman, 2016) because it has a low level of toxicity (Nurqolbiah, Kusharyanti, \& Nurbaeti, 2016; Nursid, Wikanta, \& Januar, 2017; Wikanta, Januar, \& Nursid, 2017), has bactericidal nature, and is relatively inexpensive. However, the use of povidone-iodine often causes many side effects such as pyoderma (Sari \& Setyawati, 2008; Simarmata, Meha, \& Anom, 2020). Therefore, alternative medicine is needed by using natural ingredients derived from plants
(Maulidya, 2019; Mutaqin, Noviani, Partasasmita, \& Iskandar, 2016).

Plants that contain metabolite compounds can help the wound healing process (Fernandes, Maharani, Sunarta, \& Rayan, 2018; Handayani, Sundu, \& Karapa, 2017; Wijonarko, Anies, \& Mardiono, 2016). The content of active substances such as flavonoids, saponins, and polyphenols in the kecombrang Sedian leaf extract gel is effective in healing rabbits' cut wounds (Ruslim, Anitasari, Ismail, Oli, \& Yani, 2017).

Based on research by (Yunanda \& Rinanda, 2016), onion extract is often used to heal the banana plants' wounds, such as leaves, flowers, pseudo-stems, tubers, and banana peels. Another research by (Onyenekwe, Okereke, \& Owolewa, 2013), reveals that the ointments of Ambon banana stem extract accelerate the wound healing process. Bananas contain secondary metabolites in the form of alkaloids, glycosides, terpenoids, saponins, flavonoids, and tannins(Budianto \& Basuki, 2018). Based on the statement above, it is necessary to research to test the Muli banana peels extract (Musa acuminata Colla) on the cut wound healing process on the back of mice.

\section{METHODS}

This research was conducted at the Zoology Laboratory of the Faculty of Mathematics and Natural Sciences of the University of Lampung, the Laboratory of Analytical and Instrumentation Chemistry of the Mathematics and Natural Sciences Faculty of the University of Lampung, and Pathology Laboratory Regional Veterinary Investigation and Testing Center (BPPV) Bandar Lampung in 
February to April 2019. The tools used in this study included the maintenance tools for mice (cages, feeds, and drinking containers), calipers, analytical balance, scissors and shavers, scalpels, permanent markers, beaker cups, Erlenmeyer flask, measuring cups, stirring rods, pipettes drop, aluminum foil, plastic wrap, extraction equipment (blenders, ovens, filter paper, Buchner funnels, and rotary evaporators), and cameras for documentation.

The materials used in this research included 24 male mice (Mus musculus), Muli banana skin (Musa acuminata), 96\% ethanol, povidone- iodine, 2\% lidocaine, chloroform, vegetable pellets to feed the mice, and tap water for the mice to drink. The first analysis of the obtained data the homogeneity test and then followed by the analysis of variance or ANOVA using the SPSS and Minitab programs.

\section{RESULTS AND DISCUSSION}

The length of the wound closure was measured using calipers. The following is the figure of the average percentage of the length of wound closure from day 1 to day 7.

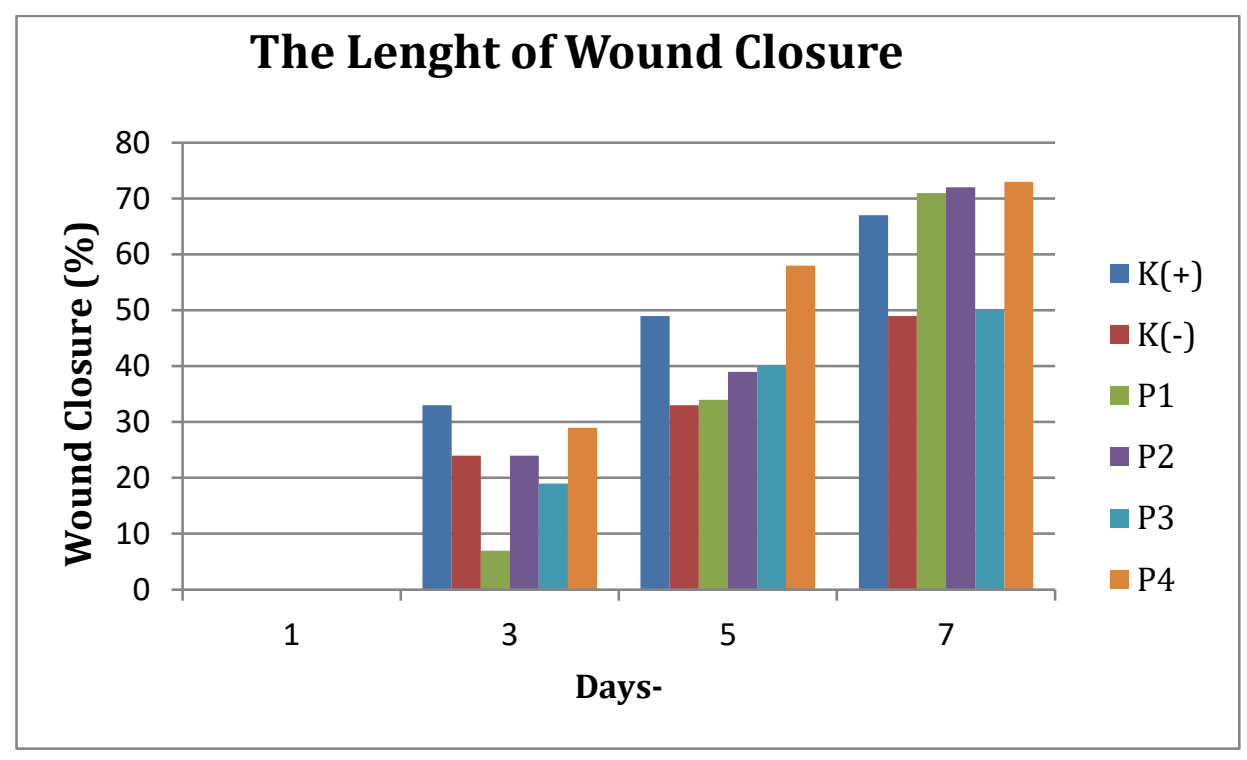

Figure 1. The Average Percentage of the Length of the Cut Wound Closure

Based on Figure 1, the average percentage of cut wound closure at day 1 was $0 \%$ because the wounds had just formed and the healing process had not occurred yet. After 7 days of treatment, the highest wound closure percentage was found in P4 with the average percentage of wound closure length reaching $73.25 \%$. Consecutively, the second-highest wound closure percentage was obtained by $\mathrm{P} 2$ with the average percentage of $72 \%$ and then followed by P1 with the average percentage of wound closure length of $71.50 \%, \mathrm{~K}+$ with the average percentage of wound closure length of
$67.25 \%$, P3 with the average percentage of wound closure length of $49.50 \%$, and $\mathrm{K}$ - with the average percentage of wound closure length of $48.50 \%$.

Wounds on mice smeared with $40 \%$ concentration of Muli banana peels ethanol extract had a faster recovery rate than the positive control $(\mathrm{K}+)$ smeared with povidone-iodine and negative control (K-) smeared with distilled water. ANOVA test results showed that there were no significant differences between treatments $(p>$ 0.05). Based on data, the average wound healing time in mice for 14 days can be seen in Figure 2 . 


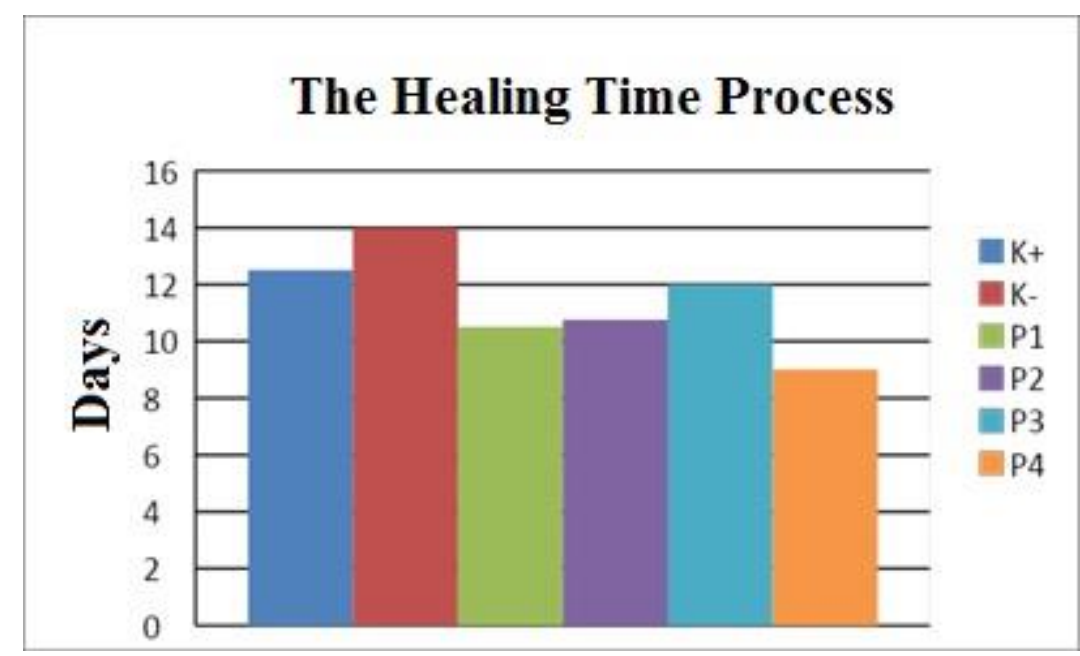

Figure 2. The Average Percentage of Wound Healing Time

Figure 2 shows that the fastest wound healing time occurred in treatment 4 (P4) with the average wound healing time within 9 days. Then consecutively, the wound healing time on treatment 1 (P1) was 10.5 days, the wound healing time on treatment 2 (P2) was 10.75 days, the wound healing time on treatment 3 (P3) was 12 days, the wound healing time on positive control was 12.25 , and the wound healing time on negative control (K-) was 14 days. ANOVA test results showed that there were no significant differences between treatments $(p>0.05)$.

Preparing the test animals. 24 male mice was grouped into 6 groups, namely positive control group $[\mathrm{K}+]$, negative control group [K-],

Preparing the test materials. Muli banana peels were cut into small pieces and then washed clean to remove the dirt that sticks under running water.

Making the cut wounds on the mice's back. Before the back of the mice was cut, the hair had been shaved clean using a razor or scissors.

Administering the extracts. The cut wounds in the $\mathrm{K}+$ group (positive control) were smeared with povide iodine and the cut wounds in the K- group (normal control) were smeared with distilled water.

Making histology slides. One mouse was taken from each group of mice to make histological slides.

Macroscopic and microscopic observations. The observations covered the wound healing time, length measurements measured using calipers, hyperemic features, granulation, and crusting.

Figure 3. The Procedure for Administering the Muli Banana Peels Ethanol Extract 
Musa acuminata contains bioactive compounds such as flavonoids $0.25 \%$, tannins $67.59 \%$, ascorbic acid $0.44 \%$, saponins $14.49 \%$, alkaloids $0.34 \%$ and lycopene $0.006 \%$ (Puspitasari \& Apriasari, 2017). Tannin compounds are compounds that have antioxidant properties. Excessive antioxidant activity in the wound healing process can inhibit the wound healing process (Kurahashi \& Fujii, 2015).

Each experimental group experienced a healing process. The positive control group was smeared with povidone-iodine. Povidone-iodine is a commonly used drug for wound healing because it is an antiseptic so that it helps to accelerate wound healing (Bigliardi et al., 2017). However, the negative control group also experienced the wound healing process even in a longer period because the body has the natural ability to protect and restore itself from injury (Govindam, Kuchi, Balekari, \& Rani, 2011).
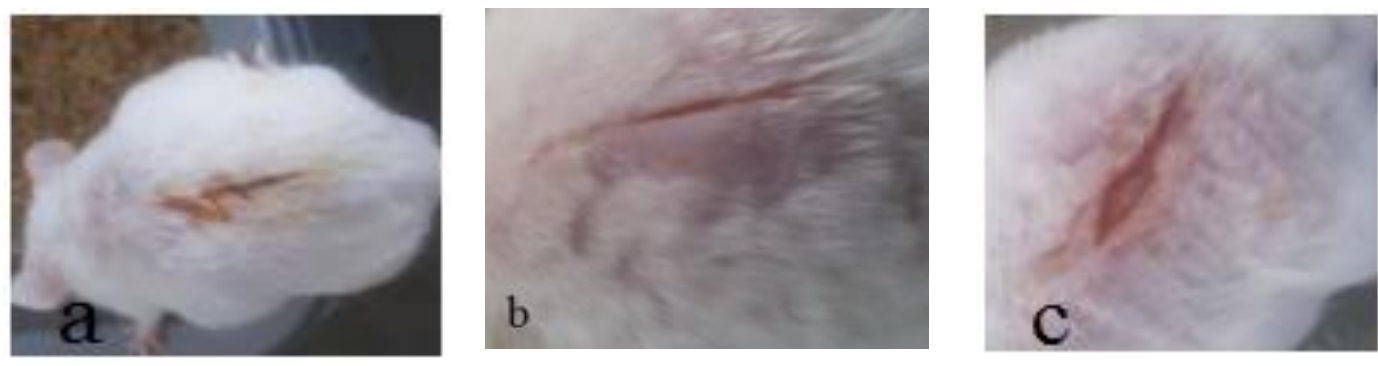

Figure 4. The Overview of Hyperemia, Granulation, and Crust

On the $5^{\text {th }}$-day, the wound on the back of the mice had begun to shrink proven by the formation of granulation and crusts marked by the formation of dried exudate or scab in each group. The observation on the $7^{\text {th }}$-day of the wound on the P4 group showed a sign of total wound healing with the absence of the attached crust as can be seen in Figure
5. Macroscopic observations were made by describing and scoring the results of the histology of mice's skin based on the description table. A 40x magnification microscope was utilized to see differences in results epithelialization, the formation of new blood vessels, and the number of inflammatory cells.
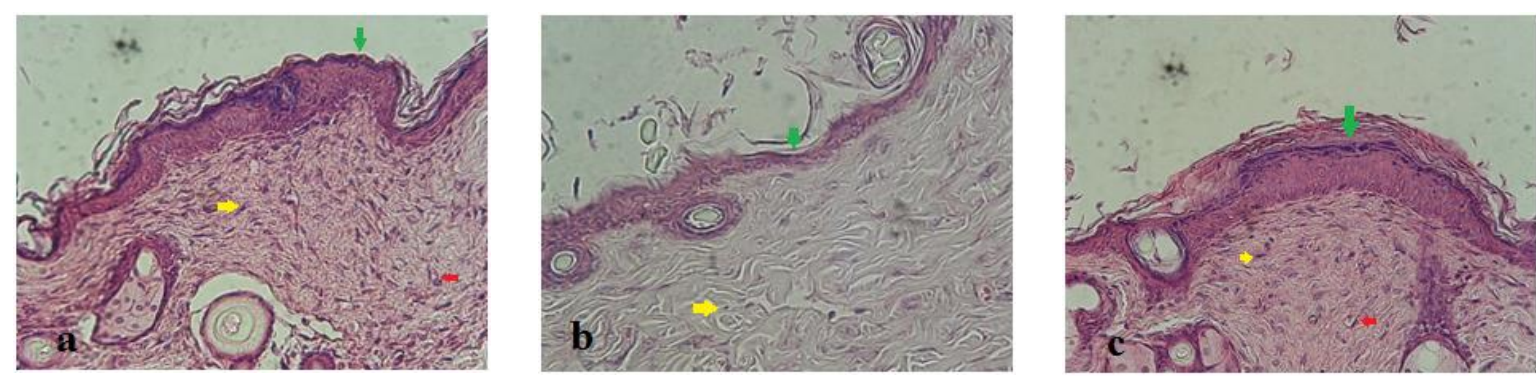


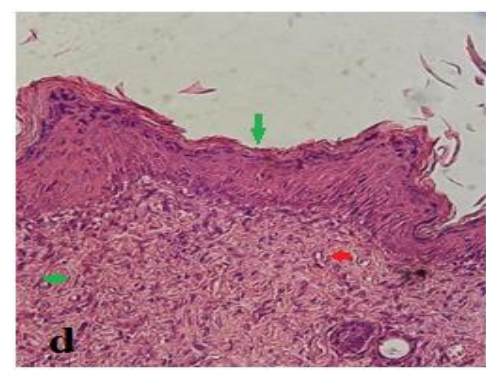

Description:

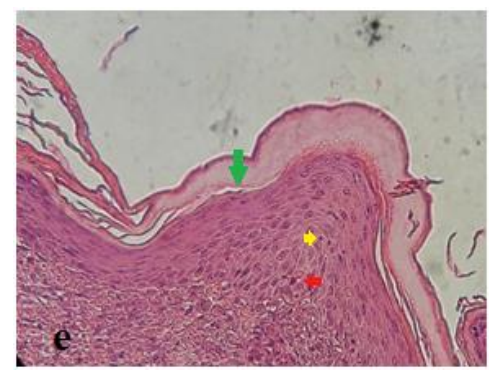

1 = Blood vessels;

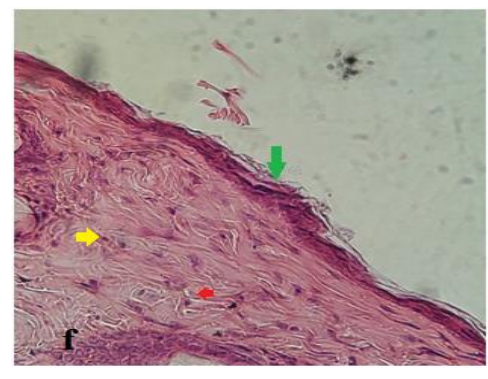

$=$ Inflammation

Figure 6. The image of the cross-sectional histology; (a) the cut wound smeared with povidone-iodine $\mathrm{K}+$, (b) the cut wound smeared with distilled water $\mathrm{K}-$, (c) the cut wound smeared with $10 \%$ of Muli banana peels ethanol extract, (d) the cut wound smeared with $20 \%$ of Muli banana peels ethanol extract (e) cut wound smeared with $30 \%$ of Muli banana peels ethanol extract, and (f) cut smeared with $40 \%$ of Muli banana peels ethanol extract.

Based on the results of the crosssectional histology of the skin of mice, the histological score of the skin can be made which can be seen in the table below.

Table 1. The Average Score of Cross-Sectional Histology on the Skin of Mice

\begin{tabular}{|c|c|c|c|c|c|}
\hline \multirow{2}{*}{ Treatment } & \multicolumn{3}{|c|}{ Score } & \multirow{2}{*}{ Total Score } & \multirow{2}{*}{ average } \\
\hline & $\mathbf{A}$ & B & C & & \\
\hline $\mathrm{K}+$ & 3 & 2 & 1 & 6 & 2 \\
\hline $\mathrm{K}$ & 2 & 1 & 1 & 4 & 1.3 \\
\hline $\mathrm{P} 1$ & 3 & 2 & 1 & 6 & 2 \\
\hline $\mathrm{P} 2$ & 3 & 3 & 1 & 7 & 2.3 \\
\hline P3 & 2 & 2 & 1 & 5 & 1.6 \\
\hline $\mathrm{P} 4$ & 3 & 3 & 2 & 8 & 2.6 \\
\hline
\end{tabular}

Table 1 shows that normal epitalization occurred in the treatment group that was given Muli banana peels ethanol extract of $10 \%, 20 \%$, and $40 \%$. The epithelium is a protective tissue that protects the tissue underneath from external disturbances in the form of mechanical or microbial (Honari, Andersen, \& Maibach, 2017). There were more than 2 new blood vessels found in the histology of the skin of the treatment group that was given the Muli banana peels ethanol extract of $20 \%$ and $40 \%$. When the tissue is regenerating blood vessels, its function is to carry oxygen and nutrients to help heal wounds (Reinke \& Sorg, 2012). There were 6-10 inflammatory cells per microscope field of view found in the skin histology of the treatment group that was given Muli banana peels ethanol extract of $40 \%$. Inflammatory cells show an inflammatory process that can function to avoid tissue from contamination caused by microorganisms (Panche, Diwan, \& Chandra, 2016).

Active compounds contained in banana peels such as flavonoids act as bacterial growth inhibition. Besides, the flavonoids and the antioxidant activity can increase epitalization (Thakur, Jain, Pathak, \& Sandhu, 2011). Saponins have antifungal properties, enhance the immune system, reduce the occurrence of blood clots and stimulate the formation of new epithelial cells, thereby, accelerating the process of reepitalization during the wound healing 
process (Prasetyo, Wientarsih, \& Priosoeryanto, 2010). Tannins serve as antimicrobial, antidiarrheal, and anthelmintic (Tiwari, Kumar, Kaur, Kaur, \& Kaur, 2011).

Based on research by (Yunanda \& Rinanda, 2016), metabolite compounds are good for wound healing by accelerating the formation of granulation tissue, contraction of the wound, fibroblast maturation, and reducing hyperemia around the wound. Muli banana plant (Musa acuminate Colla) type AAA genome, is a plant that grows in Indonesia because it is much loved by people from various backgrounds. Banana Muli is often served as a dessert in various events because it is sweet and small.

Besides, other parts of the banana plant such as leaves, flowers, pseudostems, tubers, and banana peels are often used for treatment (Onyenekwe et al., 2013). The Ambon banana stem extract ointment at a concentration of $20 \%$ can increase the number of infiltrations of inflammatory cells by four, improve neocapillary shape, accelerate the formation of fibroblasts, thus accelerating the wound healing process. Based on the statement above, it is necessary to research testing the extract of Muli banana peels (Musa acuminata Colla) on the wound healing process on the back of mice.

\section{CONCLUSIONS AND SUGGESTIONS}

Based on the results of the research, it can be concluded that the Muli banana (Musa acuminata) peels ethanol extract with a concentration of $40 \%$ was the best compared to positive and negative controls. Ethanol extract of Muli banana peels (Musa acuminata) has effects on the wound healing process, including the level of epitalization, the number of new blood vessels, and the number of inflammatory cells.

It is suggested for further researchers to conduct further research on the ethanol extract of Muli banana peels. This research can be used as a reference for subsequent research.

\section{REFERENCES}

Bigliardi, P.L., Alsagoff, S.A.L., El-Kafrawi, H.Y., Pyon, J.-K., Wa, C.T.C., Villa, M.A., 2017. Povidone iodine in wound healing: A review of current concepts and practices. Int. J. Surg. 44, 260-268. https://doi.org/10.1016/j.ijsu.2 017.06.073

Budianto, B.H., Basuki, E., 2018. Studi Toksisitas: Ekstrak Metanol Bonggol Pisang Ambon (Musa acuminata L. cv. Gros Michel) terhadap Aedes aegypti (Diptera: Culcidae). ASPIRATOR-J. VectorBorne Dis. Stud. 10, 93-102.

Darwis, D., Hardiningsih, L., Nurlidar, F., 2013. Karakteristik Sifat FisikaKimia Hidrogel Pvp-MaduGliserin Hasil Iradiasi Gamma. J. Ilm. Apl. Isot. Dan Radiasi 6.

Fernandes, A., Maharani, R., Sunarta, S., Rayan, R., 2018. Karakteristik Kimia Dan Potensi Daun Tanaman Akar Bulou (Mikania Micrantha Kunth) Sebagai Obat Luka Tradisional. J. Penelit. Ekosistem Dipterokarpa 4, 109116.

Govindam, S., Kuchi, M., Balekari, U., Rani, G.S., 2011. Screening Of Wound Healing Effect Of Bark Of 6.

Hadi, U.K., 2006. Bioekologi Berbagai Jenis Serangga Pengganggu Pada Hewan Ternak Di Indonesia dan Pengendaliannya 1-13.

Handayani, F., Sundu, R., Karapa, H.N., 2017. Uji Aktivitas Ekstrak Etanol 
Biji Pinang (Areca catechu L.) Terhadap Penyembuhan Luka Bakar pada Kulit Punggung Mencit Putih Jantan (Mus musculus). J. Ilm. Manuntung 2, 154-160.

Honari, G., Andersen, R.M., Maibach, H.I. (Eds.), 2017. Sensitive skin syndrome, Second edi. ed. CRC Press, Taylor \& Francis Group, Boca Raton.

Kurahashi, T., Fujii, J., 2015. Roles of Antioxidative Enzymes in Wound Healing. J. Dev. Biol. 3, 57-70. https://doi.org/10.3390/jdb302 0057

Maulidya, E., 2019. Uji Efektivitas Ekstrak Etanol Kulit Buah Pisang Muli (Musa acuminata Colla) Terhadap Lama Penyembuhan Luka Sayat Pada Mencit (Mus musculus Linnaeus, 1758).

Mutaqin, A.Z., Noviani, E., Partasasmita, R., Iskandar, J., 2016. Studi etnobotani pemanfaatan jenisjenis tumbuhan yang digunakan sebagai obat oleh masyarakat Desa Pangandaran Kecamatan Pangandaran Kabupaten Pangandaran, in: Prosiding Seminar Nasional MIPA. pp. 5561.

Muthia, K., Titin, S., Neneng, A., 2019. Jagung Sebagai Masker Terhadap Kesehatan Kulit Wajah Kering Secara Alami 1.

Ningsih, S., Paturusi, A.A.E., 2015. Uji efek penyembuhan gel ekstrak daun jarak merah (Jatropha gossypifolia Linn.) terhadap luka sayat pada kelinci (Oryctolagus cuniculus). J. Farm. UIN Alauddin Makassar 3, 104-110.
Nurqolbiah, E., Kusharyanti, I., Nurbaeti, S.N., 2016. Uji Toksisitas Fraksi Air Impatiens balsamina Pada Tikus Betina Galur Sprague Dawley. Pharm. Sci. Res. PSR 1, 16-29.

Nursid, M., Wikanta, T., Januar, H.I., 2017. Hubungan antara keberadaan duri dengan toksisitas karang lunak dan sponge. J. Penelit. Perikan. Indones. 11, 83-92.

Nuzantry, J.K., Widayati, R.I., 2015. Efektivitas Campuran Ekstrak Aloe Vera Dan Olive Oil Dalam Formulasi Pelembab Pada Kekeringan Kulit. Faculty of Medicine.

Oktaria, D., Fazriesa, S., 2017. Efektivitas Akupunktur untuk Rehabilitasi Stroke. J. Major. 6, 65-72.

Onyenekwe, P.C., Okereke, O.E., Owolewa, S.O., 2013. Phytochemical screening and effect of Musa paradisiaca stem extrude on rat haematological parameters. Curr. Res. J. Biol. Sci. 5, 26-29.

Panche, A.N., Diwan, A.D., Chandra, S.R., 2016. Flavonoids: an overview. J. Nutr. Sci. 5, e47. https://doi.org/10.1017/jns.201 6.41

Prasetyo, B.F., Wientarsih, I., Priosoeryanto, B.P., 2010. Aktivitas Sediaan Gel Ekstrak Batang Pohon Pisang Ambon dalam Proses Penyembuhan Luka pada Mencit 11, 4 .

Puspitasari, D., Apriasari, M.L., 2017. Analysis of traumatic ulcer healing time under the treatment of the Mauli banana (Musa acuminata) $25 \%$ stem extract gel. 
Biosfer: Jurnal Tadris Biologi, 11 (1) (2020) 17 - 25

Eriola Maulidya, M. Kanedi, Yulianty, Eti Ernawiati

Padjadjaran J. Dent. 29. https://doi.org/10.24198/pjd.vo 129no1.11598

Putrinda, A.F., Budi, H., Rudy, A., 2014. Untuk Mendiagnosa Penyakit Kulit Pada Manusia Dengan Menggunakan Metode Certainty Factor ( Studi Kasus Tempat Praktek dr . Diyanto Wirawan , Sp . KK ). J. Nas. Pendidik. Tek. Inform. JANAPATI 3, 110-117.

Reinke, J.M., Sorg, H., 2012. Wound Repair and Regeneration. Eur. Surg. Res. 49, 35-43. https://doi.org/10.1159/00033 9613

Ruslim, A.K., Anitasari, S., Ismail, S., Oli, E.M., Yani, S., 2017. Effect of African leaves extract (Vernonia amygdalina Del.) on wound healing velocity after tooth extraction in Rattus norvegicus. J. Sains Dan Kesehat. 1, 408-414.

Sari, L.M., Setyawati, T., 2008. Manifestasi Behçet disease yang parah dan komplikasi perawatannya dalam rongga mulut. J. Dent. Indones. 15, 111120.

Simarmata, Y.T., Meha, M.P.M., Anom, I.D.M., 2020. Laporan Kasus: Penanganan Transmissible Venereal Tumor Pada Anjing Lokal Di Anom Vet Clinic. J. Kaji. Vet. 8, 92-101.

Thakur, R., Jain, N., Pathak, R., Sandhu, S.S., 2011. Practices in Wound Healing Studies of Plants. Evid. Based Complement. Alternat. Med. 2011, 1-17. https://doi.org/10.1155/2011/4 38056
Tiwari, P., Kumar, B., Kaur, M., Kaur, G., Kaur, H., 2011. Phytochemical screening and extraction: a review. Int. Pharm. Sci. 1, 98-106.

Wijonarko, B., Anies, A., Mardiono, M., 2016. Efektvitas Topikal Salep Ekstrak Binahong (AnrederaCordifolia (Tenore) Steenis) terhadap Proses Penyembuhan Luka Ulkus Diabetik pada Tikus Wistar (Rattus Novergicus). J. Ilm. Kesehat. 9, 96955.

Wikanta, T., Januar, H.I., Nursid, M., 2017. Uji aktivitas antioksidan, toksisitas, dan sitotoksisitas ekstrak Alga Merah Rhodymenia palmata. J. Penelit. Perikan. Indones. 11, 41-49.

Yufdel, Y., Nasution, S.K., Harahap, S., 2015. Perbedaan Pengaruh Perawatan Luka Menggunakan Povidone Iodine Dan Eusol Terhadap Penyembuhan Luka Perineum Pada Pasien Post Partum Di Rs Fajar Medan Tahun 2015. J. Ilm. PANNMED Pharm. Anal. Nurse Nutr. Midwivery Environ. Dent. 10, 111-120.

Yunanda, V., Rinanda, T., 2016. Aktivitas penyembuhan luka sediaan topikal ekstrak Bawang Merah (Allium cepa) terhadap luka sayat kulit Mencit (Mus musculus). J. Vet. Desember 17, 606-614.

Zuhan, A., Rahman, H., Januarman, J., 2016. Profil Penanganan Luka pada Pasien Trauma di Instalasi Gawat Darurat Rumah Sakit Umum Provinsi Nusa Tenggara Barat. J. Kedokt. 5, 21-21. 